\title{
Pengaruh Kegiatan Menganyam Terhadap Konsentrasi Di Kelompok A TK Negeri Pembina Kota Selatan Gorontalo
}

\author{
Pupung Puspa Ardini ${ }^{1}$, Saskiawati Yusup 2, Setiyo Utoyo ${ }^{3}$ \\ pupung.p.ardin@ung.ac.id¹', saskiawatiyusup@gmail.com², setiyo.utoyo@gmail.com³ \\ PG-PAUD-FIP - Universitas Negeri Gorontalo1,2,3
}

\begin{abstract}
The objective of this research was to examine the effect of weaving on a child's concentration level. The research method was the experimental with pre-experimental design (one group pretest-posttest). The results of the research with 30 children as sample showed that there was difference between the average pretest and posttest. It can be seen in pretest obtained 15.97 and the standard deviation was 1.4735 while in posttest obtained 29.07 and standard deviation was 2.09981 . These results proved that there is a significant influence before and after treatment. So, there is an influence of weaving activities on children's concentration.
\end{abstract}

Keywords: weaving activities, concentration, kindergarten

\begin{abstract}
Abstrak
Tujuan penelitian untuk mengkaji data empirik pengaruh kegiatan menganyam pada tingkat konsentrasi seorang anak. Metode penelitian dipilih jenis Eksperimen dengan pre-experimental (one group pretest-posttest design. Hasil perolehan penelitian dengan jumlah sampel 30 anak terdapat adanya terkait perbedaan rata-rata hasil pretest beserta posttest. Hal ini dapat dilihat pada data pretest memperoleh 15,97 dan standar deviasi 1,47352. Hasil data posttest memperoleh 29,07 dan standar deviasi 2.09981. Hasil tersebut membuktikan bahwa terdapat pengaruh yang signifikansi pra dan setelah perlakuan. Tampilan analisis uji hipotesis diketahui bahwa thitung $\leq t_{\text {tabel }}$ yaitu $0,000 \leq 0,05$ pada taraf signifikan $5 \%$ maka hipotesis dinyatakan diterima. Sehingga hipotesis bunyi penelitian diperoleh bahwa terdapat adanya pengaruh kegiatan menganyam pada konsentrasi anak.
\end{abstract}

Kata Kunci: kegiatan menganyam, konsentrasi, taman kanak-kanak

\section{PENDAHULUAN}

Seorang anak pada rentang usia 0-6 tahun apalagi masa penjelajahan akan memiliki keunikan dimana anak akan senang bergerak, memperhatikan yang ada di sekitar sebagai uoaya dalam meniru lingkungannya. Tidak mudah bagi seorang pendidik memilih kegiatan yang dapat memusatkan perhatian anak dalam waktu lama untuk sekedar menyelesaikan kegiatannya. Berbicara tentang rentang konsentrasi anak Nuryana mengutip Sugiyanto, (Khotimah et al., 2020) akan menjadi cara yang diharapkan semua hal yang tidak penting terkesampingkan apabila sedang melakukan focus satu hal. Beragam kegiatan direncanakan oleh pendidik agar anak bisa melakukan aktivitas dengan penuh kesadaran pentingnya hasil capaian perkembangan tersebut tanpa terganggu sesuatu yang dapat merusak hasil perkembangan tersebut.

Butuh perencanaan pembelajaran yang matang dalam menentukan satu kegiatan berdasar usia anak untuk melatih daya rentang pemusatan tersebut, mengingat konsentrasi akan menjadi satu factor yang dapat menentukan keberhasilan proses belajar dimana ketika anak terlalu sibuk dengan hal lain yang tidak berkaitan dengan tugasnya anak kehilangan waktu dan juga tenaga sehingga tidak berhasil menyelesaikan tugas. Upaya merancang kegiatan dapat diupayakan mencari strategi efektif seperti dikemukakan oleh (Marlina, 2017) apabila pendidik tidak berhasil menyususun program perencanaan disesuaikan dengan usia, kondisi sarana yang dimiliki, waktu yang tepat makan tidak akan dapat melakukan sesuai tujuan pembelajaran yang ingin dicapai.

Mengingat pertimbangan akan pentingnya upaya agar anak tidak mengalami kesulitan berkonsentrasi dan juga strategi pemilihan sktivitas sangat berpengaruh pada kegiatan bermain capaian 
hasil belajar anak perlu dipertimbangkan permasalahan yang muncul di lembaga pendidikan supaya apa yang diambil sebagai solusi dapat berjalan tepat sasaran. Peningkatan konsentrasi diperlukan teknik menarik serta menyenangkan dengan merancang aktivitas bermain yang nyaman dimana anak tidak melakukan kegiaatan dengan terpaksa (Anam, Purwadi, \& Chandra, 2017) banyak hal yang mempengaruhi rentang perhatian anak dan berkaiatan dengan factor pola berpikir anak yang masih dalam jangka pendek.

Hasil pengamatan peneliti dilapangan melalui aktivitas observasi awal untuk menemukan masalah penelitian, teridentifikasi beberapa masalah yang nampak pada anak-anak yang berada di TK Negeri Pembina Kota Selatan Kota Gorontalo yang menunjukan tingkat konsentrasi yang kurang. Hal ini dapat peneliti ketahui dari berbagai gejala seperti masih terdapat anak yang belum bisa berkonsentrasi hal ini berkaitan dengan konsentrasi anak ketika didalam kelas saat proses pembelajaran, fokus perhatian, memahami, memusatkan pikiran dan memperhatikan. Selain itu, peneliti juga melihat gejala seperti kurangnya penggunaan berbagai media yang menarik untuk anak. Hal ini menandakan bahwa anak masih kurang berkonsentrasi dalam melakukan kegiatan pembelajaran didalam kelas.

Kenyataan yang terjadi saat ini bahwa tingkat konsentrasi anak tergolong masih rendah terlihat dari kemampuan anak dalam tingkat perhatian dan fokus. Terdapat 20 dari 30 anak mengalami konsentrasi yang rendah. 5 diantaranya tidak fokus pada saat guru menjelaskan langkah-langkah kegiatan menganyam melalui zoom meeting, 7 anak melakukan kegiatan diluar kegiatan menganyam dan 8 anak masih belum berkonsentrasi karena tampak di video zoom, anak keluar dari area video (Observasi awal Penelitian, Agustus 2020) . Hal ini dibuktikan dari hasil observasi langsung peneliti pada kegiatan anak saat beraktivitas di kelas, anak mengalami kesukaran terkait berkonsentrasi dan fokus ketika dikelas. Sehingga diperlukan strategi khusus atau langkah-langkah untuk menuntaskan hal tersebut. Sesuai dengan penelitian sebelumnya dalam upaya meningkatkan konsentrasi anak diperlukan strategi yang lebih khusus dalam hal ini yaitu menganyam untuk meningkatkan konsentrasi anak, sejalan dengan itu maka peneliti mengambil yang menjadi media dalam penelitian ini yaitu menganyam.

Mengapa mengayam dipilih sebagai alternative efektif untuk memecahkan masalah yang terjadi di lembaga ini tentu ada pertimbangan dimana perlu tantangan, kesabaran serta koordinasi mata, tangan serta jari-jari saat anak saat melakukan kegiatan tersebut. Selain itu anak dalam kegiatan tersebut harus teliti, luwes dikarenakan ada proses yang dilalui berpikir bagaimana hasil menumpuk dan mengaitkan potongan-potongan akan menjadi sebuah karya yang dapat dilihat nantinya. Bagian yang terpisah kemudian disatukan memiliki nilai jika sudah menjadi benda karya dibutuhkan konsentrasi dan juga tingkat imajinasi anak yang mana bahan anyaman dapat disesuaikan dengan sumber belajar yang tersedia di tempat tanpa harus mengeluarkan biaya mahal. Saat konsentrasi akan bersamaan dengan pengelolaan emosi anak dimana kegiatan mengayam anak memanafaatkan emosi positif yaitu kemampuan anak mengendalika diri pada situasi tenang, sabar dan menghadapi persoalan tugas dengan ekspresi yang wajar(Mulyana et al., 2017). Pada Beberapa wilayah Gorontalo salah satunya di Kota Selatan, Guru jarang bahkan tidak memberikan kegiatan menganyam terutama saat pandemic seperti sekarang ini. Guru beranggapan kegiatan menganyam sedikit sukar dan anak akan kesulitan menyelesaikan tugas menganyam selain itu kegiatan bermain lebih banyak dilakukan di rumah. Sehingga guru tidak merancang kegiatan menganyam pada tahun ajaran ini. Kegiatan stimulasi lebih banyak melalui kegiatan Luring melalui acara TV Edukasi lokal dan TVRI khusus untuk Siswa PAUD. 
Berdasarkan uraian tersebut, diperlukan usaha perbaikan akan dilakukan terkait peningkatan konsentrasi anak agar dapat berkembang dengan baik. Adapun cara yang dipilih dengan menganyam sebagai aktivitas yang dapat mempengaruhi konsentrasi saat pembelajaran berlangsung. Aktivitas menganyam untuk anak usia dini adalah kegiatan yang dapat mengasah keterampilan motorik halus anak karena menggunakan perpaduan jari dan tangan dengan perpaduan koordinasi dua mata. Upaya itu peneliti merumuskan hipotesis untuk dikaji lebih mendalam yakni "Terdapat Pengaruh Kegiatan Menganyam Terhadap Konsentrasi Anak Kelompok A Di TK Negeri Pembina Kota Selatan Kota Gorontalo"

\section{METODE PENELITIAN}

Desain dipilih dalam penelitian ini yaitu eksperimen dengan kegiatan menganyam sebagai treatment dimana untuk melihat pengaruh yang ditimbulkan (Sugiyono, 2017). Penjabaran variable bebas adalah kegiatan menganyam dan variable terikat adalah konsentrasi. Sample pada penelitian ini sebanyak 30 anak di TK Negeri Pembina di Gorontalo. Adapun prosedurnya sebagai berikut:

Tabel 1: One Grup Pretest-Posttest Design

\begin{tabular}{ccc}
\hline Pre-test & Treatmen & Post-test \\
\hline $\mathrm{X} 1$ & $\mathrm{~T}$ & $\mathrm{X} 2$ \\
\hline
\end{tabular}

Teknik pengumpulan data menggunakan Performance Test variable konsentrasi. Sebelum melakukan penelitian, terlebih dahulu peneliti melakukan uji coba terhadap instrument yang digunakan. Selanjutnya menentukan Uji normalitas dan Uji hipotesis. Data yang diperoleh dari penilaian ini adalah data jenis kuantitatif. Paparan hasil tes awal dan tes akhir dari konsentrasi anak. Dalam pengelolaan data jenis kuantitatif ini menggunakan bantuan software SPSS versi 16.0 for windows.

Supaya hasil valid serta dapat dipertanggung jawabkan, awal terdahulu adanya tes yang sudah disusun untuk diuji cobakan terhadap responden yaitu di TK Nusa Indah Kelurahan Pauwo Kecamatan Kabila Kabupaten Bone Bolango kelompok A. 12 butir pernyataan yang diuji cobakan, dan dinyatakan seluruhnya Valid.

Validitas merupakan alat ukur akan digunakan upaya mendapatkan data itu jadi valid. Valid dimaksud instrumen berhasil untuk digunakan terhadap pengukuran berpedoman pada rumus Product Moment. Validitas menunjukan alat pengukur yang diterapkan ukuran indicator yang dituju. Pengujian validitas selanjutnya diproses dalam computer program software SPSS 16.0 for windows. Berdasarkan output terdapat 12 butir pernyataan diuji cobakan, dan dinyatakan seluruhnya Valid. Butir pernyataan dinyatakan valid dan reabel berdasarkan hasil dari validasi setiap pertanyaan butir pernyataan melebihi dari nilai $R_{\text {tabel }} 0,444$ pada taraf signifikan 0,05 .

\section{HASIL DAN PEMBAHASAN}

Secara menyeluruh data terkumpul berhasil didapatkan hasil terkait pretest yang rata-rata 15,97. Hasil menunjukan tingkat konsentrasi dinyatakan belum maksimal karena belum menggunakan kegiatan menganyam. Kemudian nilai rata-rata posttest yaitu 29,07 dapat menyatakan kegiatan menganyam mempengaruhi konsentrasi anak.

Uji normalitas dengan uji Shapiro-wilk diperoleh uji normalitas data. Nilai tampilan signifikan data lebih dari 0,05 tertampil berdistribusi normal. Selanjutnya dilakukan pengujian hipotesis melalui uji $T$ independen sampel memanfaatkan metode pengujian memperoleh perbedaan rata-rata dan hasil Pretest dan data hasil Posttest. Dasar dari pengambilan tiap keputusan pada uji T sampel independen 
yaitu : Jika nilai signifikan $\geq 0,05$ maka $\mathrm{H} 0$ diterima dan Ha ditolak , Jika nilai siginifikan $<0,05$ maka HO ditolak dan Ha diterima.

Tabel. 2 Hasil Uji test menggunakan SPSS

\begin{tabular}{llllll}
\hline & Kelompok & $\mathrm{N}$ & Mean & Std. Deviation & Std. Error Mean \\
\hline \multirow{2}{*}{ TingkatPengetahuan } & prestest & 30 & 15.97 & 1.474 & .269 \\
\cline { 2 - 6 } & postest & 30 & 29.07 & 2.100 & .383 \\
\hline
\end{tabular}

Output Tes pada Statistics, sig.n (2-tailed) bernilai 0,000. Oleh karena nilai 0,000 $\leq 0.05$ maka hipotesis diterima. Oleh karena itulah, hipotesis dari penelitian yang menyatakan bahwa ada pengaruh kegiatan menganyam terhadap konsentrasi anak. Hal ini ditinjau dari beberapa pendapat bahwa Konsentrasi berasal dari kata concentrate (kata kerja) berarti memusatkan. Jadi konsentrasi berarti pemusatan dari pikiran terhadap suatu hal dengan cara menyampingkan akan semua hal yang tidak ada hubungannya. Menurut Surya (Waliyanti \& Pratiwi, 2017) Konsentrasi merupakan pemusatan berkaitan kekuatan berpikir dan perlakuan terhadap satu objek diamati dengan berupaya membuang atau menyisihkan beragam bentuk yang tidak memiliki kaitan pada sesuatu sebagai bahan yang dipelajari. Konsentrasi menurut Siswanto (Nurdiana, Masturoh, \& Pasya, 2018) berupa capaian kemampuan untuk fokus perhatian secara lengkap terhadap permasalahan yang sedang dihadapi. Permasalahan yang dipecahkan dapat memungkinkan seseorang untuk dapat terhindar dari pikiranpikiran yang merusak perhatian sedang berusaha untuk ketemu solusi persoalan. Memusatkan perhatian sangat erat kaitannya dengan memori (ingatan).

Menurut Schimed peper dan Wilson (Nusufi, 2018) menegaskan dari hasil yang dicapai dalam penelitian fokus perhatian menyelesaikan tugas anak juga dipengaruhi dari fator pendukung lingkungan yang kondusif. Konsentrasi akan menjadi yang dimiliki perlu adanya latihan yang tifdak instan tetapi sejak anak sejak kecil. Alasan dilakukan sejak dini anak agar membiasakan beperilaku terpusat, maka nantinya berpengaruh terhadap masa depannya. Teratur mengalami kesulitan perhatian fokus akan terus terbawa sampai dewasa sehingga memiliki kelemahan terkait berkonsentrasi. Tentu ini berbahaya pada kemampuan anak yang capaian lainnya, selain itu berpengaruh merugikan anak secara internal.

Capaian seseorang terkait berkonsentrasi akan memiliki dampak pula pada kecepatan menangkap informasi materi disampaiakan oleh pendidik. Apabila anak nantinya mencapai hasil perkembangan cukup baik dalam berkonsentrasi semakin cepat pula capaian menangkap materi saat proses pembelajaran dari pada anak mempunyai daya kemampuan konsentrasi kurang mencapai baik. Konsentrasi capaian lemah akan memiliki semangat belajar capaian lemah pula (A'la, 2010)

Walau memang ada anak dilahirkan dalam keadaan berkonsentrasi atau penuh pemusatan tinggi. Tetapi, apabila tidak diberikan rangsangan proses konsentrasi ini bisa saja terjadi penurunan. Oleh karena itu, hasil konsentrasi terus distimulus dari kecil untuk keberhasilan capaian anak. Maka dari itu orang tua dan guru sangat berperan dalam mengetahui terkait stimulasi perhatian bertahan berapakah waktu konsentrasi pertahapan usia anak. Dimana efek dari stimulasi belebih juga memiliki pengaruh pada tingkat stress pada gangguan emosi anak bisa menjadi mogok tidak mau belajar.Faktor terkait gangguan konsentrasi ditinjau dari diri anak yang memiliki kemauan kuat dalam melakukan juga pada stimulasi lingkungan yang dapat memberikan kondisi menyenangkan, menenangkan serta pengkondisian lingkungan sekitar dapat meningkatkan perhatian dan konsentrasi pada diri anak (Olivia, 2010)

Tinjauan penguat pemilihan menganyam menata (bilah, daun pandan dan sebagainya) tindihmenindih dan silang-menyilang (seperti membuat tikar, bakul). Menganyam arti pendidikan yaitu 
mengatur bilah atau lembaran-lembaran yang diatur tersebut berupa daun, janur, kertas, dan kain perca. Menganyam merupakan salah satu hasil kerajinan masyarakat indonesia. Kegiatan menganyam ini dapat menghasilkan banyak benda yang bisa dipakai. Menganyam dengan media kertas merupakan suatu kegiatan mencapai keterampilan dengan harapan dapat menghasilkan beragam barang bisa dipakai dan benda karya seni melalui cara bersilang menyusupkan atau menumpang tindihkan sehingga terjadi perpaduan yang indah (Safrita, 2019). Melalui kegiatan menganyam mempunyai unsur pendidikan memiliki koordinasi antara mata dan tangan, dimana manfaatanya: melatih keterampilan aspek motorik halus, mengembangkan sikap emosi anak yang positif, mengungkapkan hati dan perasaannya, latihan pada tingkat konsentrasi, memunculkan rasa ketika pembelajaran, anak lebih terampil cenderung kreatif, serta mengetahui beragam kerajinan secara tradisional sudah ditekuni oleh masyarakat Negara Indonesia (Ningsih, 2017) Selama ini, kegiatan menganyam tidak pernah dilakukan di sekolah tempat penelitian. Guru menganggap menganyam adalah kegiatan sukar diberikan untuk anak. Hal ini karena anak-anak aktif bergerak dan guru beranggapan jika diberikan kegiatan menganyam maka anak-anak tidak dapat menyelesaikan tugas tersebut. Namun pada kenyatannya setelah diberikan stimulasi kegiatan menganyam justru memperkuat konsentrasi anak sebagai bekal bagi anak menuju tingkatan pendidikan selanjutnya di Sekolah dasar yang memerlukan banyak konsentrasi untuk memahami konsep-konsep materi.

Selanjutnya untuk memperkuat terujinya hasil penelitian berdasarkan kajian penelitian yang dilakukan Daulay terkait aktivitas menganyam mempengaruhi ketrampilan aspek motorik halus anak. Hal ini sejalan terhadap teori Aminah yang menjabarkan factor seni menganyam dapat melatih terampil dalam aspek fisik motorik halus, dimana koordinasi antara mata serta tangan, khususnya jari yang bergerak. Menganyam digunakan sebagai alat untuk melatih logika dan melatih konsentrasi terhadap anak usia dini (Daulay \& Nurmaniah, 2019). Penguat lain hasil penelitian ini ditunjang oleh teori proses informasi. (Wolfolk, 2010) Menganyam berfungsi sebagai stimulasi agar anak terlatih konsentrasinya sehingga dapat membantu penyerapan informasi pengetahuan lainnya. Menganyam dan konsentrasi akan berkaitan seperti ditegaskan pulan oleh (Darlia \& Saranani, 2019)

\section{SIMPULAN}

Berdasarkan pembahasan paparan penelitian eksperimen peneliti memperoleh kesimpulan bahwa ada pengaruh kegiatan menganyam terhadap konsentrasi anak. Berdasarkan hasil analisis bahwa, data pre-test capaian 15,97 rata-rata anak-anak belum berkembang dan standar deviasi 1,47352. Sedangkan post-test diperoleh nilai rata-rata 29,07 rata-rata anak-anak sudah berkembang setelah diberikan perlakuan/treatment kegiatan menganyam dan standar deviasi 2,09981. Responden yang menjadi sampel dalam penelitian ini memperoleh peningkatan hasil rata-rata dari tes awal sampai tes akhir sehingga dapat dikatakan bahwa kegiatan menganyam mempengaruhi konsentrasi anak.

Dengan demikian berdasarkan simpulan penelitian, harapan yang ingin dituliskan oleh peneliti pemahaman terkait bagaimana stimulasi yang dilakukan yaitu dengan aktivitas mengayam sebaiknya dapat dipertimbangkan oleh pendidik di lembaga PAUD sebagai salah satu pemilihan efektif aktivitas bermain yang dapat memiliki dampak pemusatan perhatian anak yang dalam rentang konsentrasi jarak pendek. Tentu saja ini masih bisa dikembangkan oleh pendidik dengan pemilihan media yang sesuai dengan sumber belajar di sekitar dalam mengayam juga pada aspek lain yang tentunya secara holistic harus dilakukan pada anak. 
Efektor, Volume 8 Issue 2, 2021, Pages 53-58

Pupung Puspa Ardini, Saskiawati Yusup, Setiyo Utoyo

\section{DAFTAR RUJUKAN}

A'la, M. (2010). Tips Asah Ketajaman Konsentrasi Belajar Anak Setajam Silet. Yogyakarta: Flashbook.

Anam, K., Purwadi, \& Chandra, A. (2017). Upaya Meningkatkan Konsentrasi Belajar Anak Melalui Bermain Papan Titian di TK Indiria Desa Kutosari Kecamatan Gringsing Kabupaten Batang. PAUDIA: Jurnal Penelitian dalam Bidang Pendidikan Anak Usia Dini, 6(2), 99-126. doi:https://doi.org/10.26877/paudia.v6i2.2106

Daulay, W. C., \& Nurmaniah. (2019, Desember). Pengaruh Kegiatan Menganyam Terhadap Keterampilan Motorik Halus Pada Anak Usia 5-6 Tahun di TK Al Ihsan Medan T.A 2018/2019. Jurnal Usia Dini, 5(2), 7-19. Diambil kembali dari https://jurnal.unimed.ac.id/2012/index.php/jud/article/viewFile/16200/12652

Darlia, D., \& Saranani, M. S. (2019). MENINGKATKAN KEMAMPUAN MOTORIK HALUS ANAK MELALUI KEGIATAN MELUKIS. JURNAL RISET GOLDEN AGE PAUD UHO, 2(2), 94.

Khotimah, S. H., Sunaryati, T., \& Suhartini, S. (2020). Penerapan Media Gambar Sebagai Upaya dalam Peningkatan Konsentrasi Belajar Anak Usia Dini. Jurnal Obsesi : Jurnal Pendidikan Anak Usia Dini, 5(1), 676. https://doi.org/10.31004/obsesi.v5i1.683

Marlina, L. (2017). PERENCANAAN PEMBELAJARAN PENDIDIKAN ANAK USIA DINI. Raudhatul Athfal: Jurnal Pendidikan Islam Anak Usia Dini, 1(2). https://doi.org/10.19109/ra.v1i2.2679

Mulyana, E. H., Gandana, G., \& Muslim, M. Z. N. (2017). Kemampuan Anak Usia Dini Mengelola Emosi. Jurnal PAUD Agapedia, 1(2), 214-232.

Ningsih, N. U. (2017). Peningkatan Keterampilan Motorik Halus Anak Melalui Kegiatan Menganyam Dengan Berbagai Media Pada kelompok A2 TK Sultan Agung Ngaglik Tahun Ajaran 2016/2017. Yogyakarta: Universitas Negeri Yogyakarta.

Nurdiana, M. A., Masturoh, I., \& Pasya, R. (2018). Hubungan antara Fase Merangkak dengan daya Konsentrasi Anak Usia Dini. Bestari : Jurnal Studi Pendidikan islam, 15(1), 75-94. Diambil kembali dari https://riset-iaid.net/index.php/bestari/article/view/148

Nusufi, M. (2018). Melatih Konsentrasi dalam Olah raga. Jurnal Ilmu Keolahragaan, 15(2), 55. Diambil kembali dari https://jurnal.unimed.ac.id/2012/index.php/JIK/article/view/6139/0

Olivia, F. (2010). Mendampingi Anak Belajar Bebaskkan Anak Dari Stres Dan Depresi Belajar. Jakarta: Elex Media Komputindo.

Safrita, A. W. (2019). Peningkatan Perkembangan Motorik Halus Pada Anak Usia Dini Melalui Kegiatan Menganyam Pada Kelompok B TK Candra Puspita Kecandran Salatiga Tahun Pelajaran 2018/2019. Salatiga: IAIN Salatiga. Diambil kembali dari http://erepository.perpus.iainsalatiga.ac.id/5387/

Sugiyono. (2017). Metode Penelitian Pendidikan. Bandung: Alfabeta CV.

Waliyanti, E., \& Pratiwi, W. (2017, June 10). Hubungan Derajat Insomnia Dengan Konsentrasi Belajar Mahasiswa Program Studi Ilmu Keperawatan di Yogyakarta. Indonesian Journal of Nursing Practices, 1(2). Diambil kembali dari https://garuda.ristekbrin.go.id/documents/detail/630440

Wolfolk, A. E. (2010). Educational Psychology: Active Learning Edition. London: Pearson/Allyn and Bacon Publishers. 